\title{
A Comparative Study of Three Intelligent Techniques for Malaria in Africa Continent
}

\author{
Khalda F.Ali \\ Faculty of Information Science \\ and Technology, Institute of \\ Visual Informatics,University \\ Kebangsaan Malaysia 43600 \\ Bangi, Selangor Darul Ehsan, \\ Malaysia
}

\author{
Amir Mohamed.Elamir \\ Faculty of Information Science \\ and Technology, University \\ Kebangsaan Malaysia 43600 \\ Bangi, Selangor Darul Ehsan, \\ Malaysia
}

\author{
Riza M.Suliman \\ Faculty of Information Science \\ and Technology, Institute of \\ Visual Informatics,University \\ Kebangsaan Malaysia 43600 \\ Bangi, Selangor Darul Ehsan, \\ Malaysia.
}

\begin{abstract}
Diseases are endemic in the Africa continent and one of the problems that affect economic development, malaria and fever is considered one of the most endemic diseases in eastern and central Africa, where Sudan is considered one of the countries in this region where the disease parasite. The proportion of the common symptoms of several types of fevers in this geographical area of Africa it is difficult in many cases determine the malaria fever for other fevers and thus may lead to give the patient treatment is not correct. Through this paper we compare three techniques to help in the diagnosis of malaria fever and other fevers thus giving the correct treatment and to fight the disease and minimize its spread. These techniques which will be used are neural network, genetic algorithm and fuzzy logic.
\end{abstract}

\section{Keywords}

Neural networks, genetic algorithm, fuzzy logic, endemic diseases, parasite, asymptomatic malaria, epidemiological.

\section{INTRODUCTION}

We Continued growth and rapid growth in the IT field can benefit from it in the process of diagnostic accuracy, and thus determine the correct treatment without mixing with the rest of other diseases. Is artificial intelligence and one from within the computer science that have helped in the process of determining the characteristics and qualities of diseases including malaria., Malaria is one of the most serious diseases that cause of death in Africa, especially those located in or near the equator line. Human beings always make mistakes and because of their limitation diagnosis would give the major issue of human expertise. So, computer is widely used to help the physician from diagnosing the critical cases. As neural networks can do wonders with missing data, it is widely used for medical applications. Genetic Algorithm is used to reduce the problem of malaria vectors (Anopheles mosquitoes) shifting from their traditional locations to invade new zones is an important concern. Also in this paper we apply a fuzzy logic approach for classifying the shape of a mass. As well as information that lead to earlier diagnosis and more efficient treatment.We will make comparison study between AI techniques in which their performance, accuracy and another measures.

\section{Related research}

All 2.1 In(Judith A Omumbo 2004) conducted a research study in Kenya that addressed the spread of the malaria parasite in the most important age group is children from the ages of one to 15 years of age Use the model climate-driven fuzzy model of suitability (FCS) for stable transmission developed by the Mapping Malaria Risk in Africa collaboration (MARA). Where the composition of a threeclasses $(0 \%,>0-<25 \%$ and $\geq 25 \%)$ and three classes of FCS $(0,>0-<0.75$ and $\geq 0.75)$ were tested using the kappa $(\mathrm{k})$ statistic and examined as continuous variables to define better levels of agreement. He has built the form on the following equation:

$$
y=\cos ^{2}\left[(x-U) /(S-U) \div \frac{\pi}{2}\right.
$$

As they represent $\mathrm{x}$ is a climate parameter, $\mathrm{U}$ is the value of $\mathrm{x}$ when conditions are unsuitable, and $\mathrm{S}$ is the value of $\mathrm{x}$ when conditions are suitable. When $S$ is greater than $U$ the suitability $(1-y)$, increases with $\mathrm{x}$; when $\mathrm{S}$ is less than $\mathrm{U}$ the suitability $\mathrm{y}$, decreases as $\mathrm{x}$ increases. The model defines a monthly increasing curve $(\mathrm{S}=22 \mathrm{C}, \mathrm{U}=18 \mathrm{C})$ and decreasing curve $(\mathrm{S}=22 \mathrm{C}, \mathrm{U}=40 \mathrm{C})$ for mean diurnal air temperature, a monthly increasing curve $(\mathrm{S}=80 \mathrm{~mm}, \mathrm{U}=0 \mathrm{~mm})$ for rainfall, and a single increasing curve $(\mathrm{S}=6 \mathrm{C}, \mathrm{U}=4 \mathrm{C}$ ) for annual minimum temperature. The results were as shown in the following table:

Table 1. Agreement between parasite prevalence categories among 217 surveys spatially congruent categorical values of the Fuzzy Climate Suitability (FCS) using the 0.75 threshold for stable endemic malaria.

\begin{tabular}{|c|c|c|c|c|}
\hline Graphics & FCS=0.00 & FCS $>\mathbf{0}-<\mathbf{0 . 7 5}$ & FCS $>=\mathbf{0 . 7 5}$ & Totals \\
\hline $\begin{array}{c}\text { Parasite } \\
\text { prevalence } \\
0 \%\end{array}$ & 3 & 5 & 0 & 8 \\
\hline $\begin{array}{c}\text { Parasite } \\
\text { prevalence } \\
0>-<25 \%\end{array}$ & 6 & 58 & 8 & 72 \\
\hline $\begin{array}{c}\text { Parasite } \\
\text { prevalence } \\
>=25 \%\end{array}$ & 0 & 58 & 97 & 137 \\
\hline Totals & 9 & 121 & 87 & 217 \\
\hline
\end{tabular}

2.2 In (2009 conducted a research study carried out by Henri EZ Tonnang) talked about three types of female mosquito carrying the malaria parasite, the study also spoke about the impact of weather changes in the spread of these three types of female mosquito. He has been used by The genetic algorithm for rule-set prediction (GARP) model was used to predict the geographical and ecological distribution of three 
species of the A. gambiae complex (A. gambiae, A. arabiensis, and Anopheles quadriannulatus). Has been adopted to construct the model on the following mathematical equations:

$$
\begin{aligned}
& \text { 1. } \mathrm{GI}_{\mathrm{A}}=\sum_{i=1}^{52} \frac{T W^{*} M W}{52}, \\
& \text { 2. } \mathrm{SI}=\left(1-\frac{C S}{100}\right)\left(1-\frac{D S}{100}\right)\left(1-\frac{H S}{100}\right)\left(1-\frac{W S}{100}\right), \\
& \mathrm{SX}=\left(1-\frac{C D X}{100}\right)\left(1-\frac{C W X}{100}\right)\left(1-\frac{H D X}{100}\right)\left(1-\frac{H W X}{100}\right), \\
& \text { 4. } \mathrm{EI}=\mathrm{GI}_{\mathrm{A}}^{* S I} * S \times,
\end{aligned}
$$

Where: TIW and MIw represent the weekly temperature and moisture respectively, 52 is the number of weeks in a year. CS, DS, HS and WS are the annual cold, dry, heat and wet stress respectively. CDX, CWX, HDX, HWX and EI are the annual cold-dry, cold-wet, hot-dry,hot-wet and ecoclimatic index stress interactions respectively. The model was used CLIMEX in sub-Saharan areas of Africa, by which the parasite carrier of the disease while taking into account the environmental factors affecting the lives of intermediate carrier of the disease is temperature and humidity were the

\begin{tabular}{|c|c|c|}
\hline \multirow[b]{2}{*}{ Parameter designation } & \multicolumn{2}{|c|}{ Values } \\
\hline & $\begin{array}{c}\text { A. } \\
\text { gambiae }\end{array}$ & $\begin{array}{c}\text { A. } \\
\text { arabiensis }\end{array}$ \\
\hline \multicolumn{3}{|l|}{$\begin{array}{l}\text { Moisture parameters (proportion } \\
\text { of soil moisture holding capacity) }\end{array}$} \\
\hline $\begin{array}{l}\text { Lower threshold of soil moisture } \\
\text { (SMO) }\end{array}$ & 0.35 & 0.15 \\
\hline $\begin{array}{l}\text { Lower limit of optimal range of soil } \\
\text { moisture (SM1) }\end{array}$ & 0.70 & 0.40 \\
\hline $\begin{array}{l}\text { Upper limit of optimal range of soil } \\
\text { moisture (SM2) }\end{array}$ & 1.50 & 0.60 \\
\hline $\begin{array}{l}\text { Upper threshold of soil moisture } \\
\text { (SM3) }\end{array}$ & 2.50 & 0.80 \\
\hline \multicolumn{3}{|l|}{ Temperature parameter $(\mathrm{CO})$} \\
\hline $\begin{array}{l}\text { Lower threshold of temperature for } \\
\text { population growth (DVO) }\end{array}$ & 15 & 18 \\
\hline $\begin{array}{l}\text { Lower optimal temperature for } \\
\text { population growth (DV1) }\end{array}$ & 28 & 30 \\
\hline $\begin{array}{l}\text { Upper optimal for temperature for } \\
\text { population growth (DV2) }\end{array}$ & 35 & 38 \\
\hline $\begin{array}{l}\text { Upper threshold of temperature for } \\
\text { population growth (DV3) }\end{array}$ & 40 & 44 \\
\hline \multicolumn{3}{|l|}{ Cold-wet stress indices } \\
\hline $\begin{array}{l}\text { Degree - days threshold of cold-wet } \\
\text { stress (DTCW) }\end{array}$ & 30.00 & - \\
\hline
\end{tabular}
results, as shown in the following table:

\begin{tabular}{|c|c|c|}
\hline $\begin{array}{l}\text { Moisture threshold of cold-wet stress } \\
\text { (MTCW) }\end{array}$ & 0.100 & - \\
\hline $\begin{array}{l}\text { Rate of accumulation of cold-wet } \\
\text { stress (PCW) }\end{array}$ & 0.001 & - \\
\hline \multicolumn{3}{|l|}{ Dry stress indices } \\
\hline $\begin{array}{l}\text { Soil moisture dry stress (proportion } \\
\text { of soil holding capacity) (SMDS) }\end{array}$ & 0.260 & 0.300 \\
\hline $\begin{array}{l}\text { Rate of accumulation of dry stress } \\
\text { (HDS) }\end{array}$ & -0.006 & -0.001 \\
\hline \multicolumn{3}{|l|}{ Wet stress indices } \\
\hline $\begin{array}{l}\text { Soil moisture wet stress (proportion } \\
\text { of soil holding capacity) (SMWS) }\end{array}$ & 2.50 & 0.900 \\
\hline $\begin{array}{l}\text { Rate of accumulation of wet stress } \\
\text { (HWS) }\end{array}$ & 0.20 & 0.003 \\
\hline \multicolumn{3}{|l|}{ Heat stress indices } \\
\hline Threshold of heat stress (TTHS) & 40.00 & 44.00 \\
\hline $\begin{array}{l}\text { Rate of accumulation of heat stress } \\
\text { (TTHS) }\end{array}$ & 0.001 & 0.0002 \\
\hline \multicolumn{3}{|l|}{ Cold stress indices } \\
\hline $\begin{array}{l}\text { Temperature threshold of cold stress } \\
\text { (TTCS) }\end{array}$ & 2.00 & 2.00 \\
\hline $\begin{array}{l}\text { Rate of accumulation of cold stress } \\
\text { (THCS) }\end{array}$ & -1.000 & -1.000 \\
\hline $\begin{array}{l}\text { Degree-days threshold of cold } \\
\text { stress(DTCS) }\end{array}$ & 25.000 & 15.000 \\
\hline $\begin{array}{l}\text { Rate of accumulation of cold stress } \\
\text { linked to degree-days(DHCS) }\end{array}$ & -0.002 & -0.001 \\
\hline
\end{tabular}

Table 2. CLIMEX parameters values for African malaria vectors to the Anopheles gambiae complex
2.3 The application of artificial neural Networks to increase the accuracy of diagnosis of the symptoms of malaria were not available earlier study in the continent of Africa to facilitate the search process, but there is a study conducted in Brazil, addressed to determine the symptoms of malaria, using artificial neural Networks, has been the choice of Brazil as it is located in the same latitude, the same environment Climate This study was conducted in May 2010, was conducted by Bruno B Pndrade, having concluded that the diagnostic accuracy rate rose to $80 \%$ of what was in the past. To increase this rate used microscopy, nested PCR and an expert computational system based on artificial neural networks (MalDANN) using epidemiological data were compared with Compared to the rapid screening rapid diagnosis test (RDT). The following graph and table shows how to use the model:

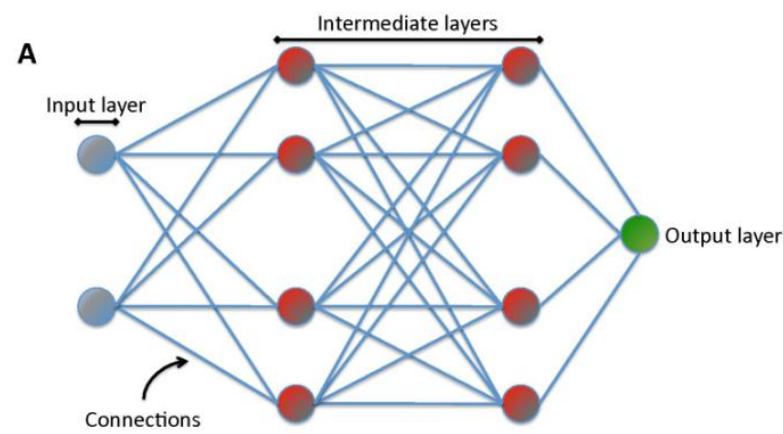




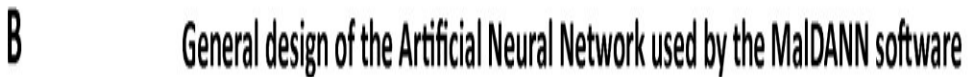

\begin{tabular}{|c|c|c|c|c|}
\hline Softwape version & \multicolumn{2}{|c|}{ Input laper } & OLintermedidite layers & Output layer \\
\hline \multirow{4}{*}{$\begin{array}{l}\text { MaDANN } \\
\text { Epidenilogic }\end{array}$} & Nevorons & Variables inuted & Nevrons & INerous \\
\hline & 31 neworns & Eipderiologicalavariabes & 1. neverons & Ol newron \\
\hline & Fiddentiologital & Sex & Dataporcessing to to & 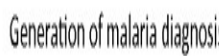 \\
\hline & varidales $e^{*}$ & 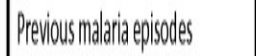 & identitypatterns & \\
\hline \multirow{4}{*}{ 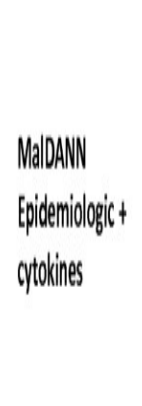 } & & 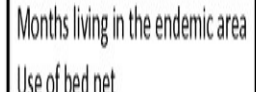 & & \\
\hline & O7 neworns & \multirow{3}{*}{ 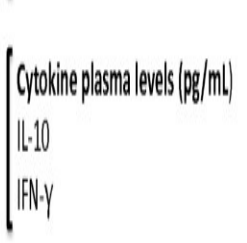 } & lonewrons & Ol neuron \\
\hline & 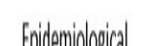 & & 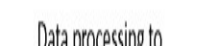 & 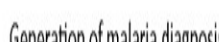 \\
\hline & $\begin{array}{l}\text { varidelestydodine } \\
\text { levels }\end{array}$ & & idertifypatems & \\
\hline
\end{tabular}

\subsection{Artificial neural network}

Artificial neural networks (ANNs) are commonly known as biologically inspired, highly sophisticated analytical techniques, capable of modeling extremely complex nonlinear functions. Formally defined, ANNs are analytic techniques modeled after

the processes of learning in the cognitive system and the neurological functions of the brain and capable of predicting specific variables from other external variables after executing a process of so-called learning from existing data[25].

\subsection{Genetic Algorithm}

GA are efficient search methods based on the principles of natural selection and population genetics in which random operators on a population of candidate solutions are employed to generate new points in the search space [26].

\section{DISCUSSION}

The present study used different artificial intelligence techniques that have their own advantages and disadvantages. The artificial neural network model is more flexible because it allows the construction of the model for the non-liner input variables.However, the relationship between each input variable and output variable in the construction process is a black box that is difficult to explain. Genetic algorithms can be introduced easily into new problem domains, due to their operation requiring only a very small amount of problemspecific knowledge A drawback of the domain independence is that a genetic algorithm sometimes achieves only a near optimal performance level, however, this problem can be tackled by exploiting the problem knowledge.

Fuzzy logic appears as a useful tool to perform decision making in real life problems.

The techniques are aimed to reduce the diagnosis time as well as increasing the accuracy percentage in classifying mass in malaria.

Fuzzy logic approach can be used to formalize and determine the fever of malaria that makes it very important in diagnosis.

\section{CONCLUSION}

The prediction of clinical outcome of patients after malaria plays an important role in medical tasks like diagnosis and treatment planning. These kinds of estimations are currently performed by clinicians using non-numerical techniques. Artificial neural networks are shown to be a powerful tool for analyze data sets where there are complicated non-linear interactions between the input data and the information to be predicted, and fuzzy logic appears as an useful tool to perform decision making in real life problems especially as the continent of Africa a high incidence of endemic diseases that affect the lives of human African. 


\section{REFERENCES}

[1] [1] Snow RW, Gouws E, Omumbo JA, Rapuoda BA, Craig MH, Tanser FC, le Sueur D, Ouma J: Models to predict the intensity of Plasmodium falciparum transmission: applications to the burden of disease in Kenya. Trans Roy Soc Trop Med Hyg 1998 , 92:601606. Kleinschmidt I, Omumbo JA, Briët O, van de Giesen N, Sogoba N, Mensah N, Windmeijer P, Moussa $\mathrm{M}$, Teuscher T: An empirical malaria distribution map for West Africa.

[2] Trop Med Int Health 2001 , 6:779-786. Briët OJT, Gunawardena DM, van der Hoek W, Amerasinghe FP: Sri Lanka malaria maps.

[3] Malar J 2003 , 2:22-32Hay SI: An overview of remote sensing and geodesy for epidemiology and public health application

[4] Adv Parasitol 2000 , 47:1-35Craig MH, Snow RW, le Sueur D: A climate-based distribution model of malaria transmission in sub-Saharan Africa.

[5] Parasitol Today 1999 , 15:105-111. PAHO: Status of malaria programmes in the Americas (based on 2002 data). Report of the 44th directing council, 55th session of the regional committee.

[6] Pan American Health Organization (PAHO)/World Health Organization (WHO): Washington D.C 2003.

[7] Hay SI, Guerra CA, Tatem AJ, Noor AM, Snow RW: The global distribution and population at risk of malaria: past, present and future.

[8] Lancet Infect Dis 2004 , 4:327-336. World Health Organization: The Africa Malaria Report 2003.

[9] World Health Organization/United Nations Children's Fund: Geneva/New York 2003, 120

[10] World Health Organisation: Rolling back malaria. The world health report 1999: making a difference.

[11] World Health Organization: Geneva 1999 , 49-63.

[12] Snow RW, Craig MH, Deichmann U, Marsh K: Estimating mortality an disability due to malaria among Africa's non-pregnant population.

[13] Bull World Health Organ 1999 , 77:624-640Snow RW, Craig MH, Newton CRJC, Steketee RW: The public health burden of Plasmodium falciparum malaria in Africa: deriving the numbers. Working Paper 11, Disease Control Priorities Project.

[14] Fogarty International Center, National Institutes of Health: Bethseda, Maryland 2003.

[15] Snow RW, Omumbo JA: Malaria mortality in subSaharan Africa (in press)

[16] In Disease and mortality in sub-Saharan Africa (Edited by: Jamison D, Feacham R, Makgoba W, Hofman K, Rogo K). Oxford University Press \& World Bank 2004 , in press.

[17] Omumbo JA, Ouma J, Rapuoda B, Craig MH, le Sueur D, Snow RW: Mapping malaria transmission intensity using geographical information systems (GIS): an example from Kenya.

[18] Ann Trop Med Parasitol 1998 , 92:7-21MARA/ARMA: Towards an atlas of malaria risk in Africa. Fist technical report of the MARA/ARMA collaboration. MARA/ARMA. Durban 1998.

[19] Directorate of Overseas Surveys: 1:50,000 topographical maps. Series Y731.

[20] Survey of Kenya: Nairobi, Kenya 1971.

[21] Central Bureau of Statistics: 1999 population and housing census: counting our people for development. Volume 1.1 Population distribution by administrative and urban centres. Ministry of Finance \& Planning, Nairobi, Kenya. 2001.

[22] GDE Systems: Populated places: GeoName Digital Gazetteer v.1 (CD-ROM).

[23] Geographic Information Department (MZ 1211-M), GDE Systems Inc., P.O. Box 509009, San Diego, California 1995.

[24] World Resources Institute: Topographic data: Africa Data Sampler (CD-ROM).

[25] World Resources Institute, USA 1995.

[26] SALB: Second Administrative Level Boundaries (SALB) Project overviews: concepts, progress and future [http://www3.who.int/whosis/gis/salb/salb\%20po.htm] webcite 2004

[27] Snow RW, Gilles HM: The epidemiology of malaria.

[28] In Bruce Chwatt's Essential Malariology (Edited by: Warrell D, Gilles H). Arnold Publishers: London 2002, 85-106.

[29] Service M: Mosquito (Diptera: Culicidae) dispersal - the long and short of it.

[30] J Med Entomol 1997 , 34:579-588. Cohen J: A coefficient of agreement for nominal scale.

[31] Educ Psychol Measurements 1960 , 20:37-46.

[32] Landis J, Koch G: The measurement of observer agreement for categorical data.

[33] Biometrics 1977 , 33:159-174

[34] Metselaar D, Van Theil P: Classification of malaria.

[35] Trop Geog Med 1959 , 11:157-161.

[36] Small J, Goetz SJ, Hay SI: Climatic suitability for malaria transmission in Africa, 1911-1995.

[37] Levine RS, Peterson AT, Benedict MQ: Geographic and ecologic distributions of the Anopheles Gambiea complex predicted using a genetic algorithm.

[38] Am J Trop Med Hyg 2004 , 70:105-109. Gillies MT, De Meillon B: The Anophelinae of Africa South of the Sahara. Publication no. 54. Johannesburg, South Africa. South African Institute of Medical Research; 1968.

[39] Gillies MT, Coetzee M: Supplement to the Anophelinae of Africa South of the Sahara. Publication no. 55 Johannesburg, South Africa. South African Institute of Medical Research; 1987.

[40] Lindsay SW, Parson L, Thomas CJ: Mapping the ranges and relative abundance of the two principal African malaria vectors, Anopheles gambiae sensu stricto and An. arabiensis, using climate data.

[41] Proc R Soc Lond B Biol Sci 1998 , 265:847-854. 
[42] Coetzee M, Craig M, Le Sueur D: Distribution of African malaria mosquitoes belonging to the Anopheles gambiae Complex.

[43] Parasitol Today 2000 , 16:74-77.

[44] Proc Natl Acad USA 2003 , 100:15341-15345

[45] Greenwood B, Mutabingwa T: Malaria in 2002. Nature $2002,415: 670-672$.

[46] Alexander N, Schellenberg D, Ngasala B, Petzold M, Drakeley C, Sutherland C: Assessing agreement between malaria slide density readings.

[47] Malar J 2010 , 9:4. Bowers KM, Bell D, Chiodini PL, Barnwell J, Incardona S, Yen S, Luchavez J, Watt H: Inter-rater reliability of malaria parasite counts and comparison of methods. Malar J 2009 , 8:267

[48] Coleman RE, Maneechai N, Rachaphaew N, Kumpitak C, Miller RS, Soyseng V, Thimasarn K, Sattabongkot J: Comparison of field and expert laboratory microscopy for active surveillance for asymptomatic Plasmodium falciparum and Plasmodium vivax in western Thailand.
[49] Am J Trop Med Hyg 2002 , 67:141-144. Khairnar K, Martin D, Lau R, Ralevski F, Pillai DR: Multiplex realtime quantitative PCR, microscopy and rapid diagnostic immuno-chromatographic tests for the detection of Plasmodium spp: performance, limit of detection analysis and quality assurance.

[50] Malar J 2009 , 8:284.

[51] Shokoples SE, Ndao M, Kowalewska-Grochowska K, Yanow SK: Multiplexed real-time PCR assay for discrimination of Plasmodium species with improved sensitivity for mixed infections. J Clin Microbiol 2009 , 47:975-980

[52] Haykin S, Neural networks: A comprehensive foundation., New Jersey: Prentice Hall, 1998.

[53] Goldberg DE, Genetic algorithm in search, optimization, and machine learning, Addison-Wesley, Reading, MA, 1989. 